\title{
No effect of running and laboratory housing on adult hippocampal neurogenesis in wild caught long-tailed wood mouse Thomas Hauser ${ }^{\dagger}$, Fabienne Klaus ${ }^{\dagger}$, Hans-Peter Lipp and Irmgard Amrein*
}

\author{
Address: Institute of Anatomy, University of Zürich, Winterthurerstrasse 190, 8057 Zürich, Switzerland \\ Email: Thomas Hauser - t.hauser@anatom.uzh.ch; Fabienne Klaus - f.klaus@anatom.uzh.ch; Hans-Peter Lipp - hplipp@anatom.uzh.ch; \\ Irmgard Amrein* - i.amrein@anatom.uzh.ch \\ * Corresponding author †Equal contributors
}

Published: 6 May 2009

BMC Neuroscience 2009, 10:43 doi:10.1 186/147|-2202-10-43
Received: 13 October 2008

Accepted: 6 May 2009

This article is available from: http://www.biomedcentral.com/I47I-2202/10/43

(c) 2009 Hauser et al; licensee BioMed Central Ltd.

This is an Open Access article distributed under the terms of the Creative Commons Attribution License (http://creativecommons.org/licenses/by/2.0), which permits unrestricted use, distribution, and reproduction in any medium, provided the original work is properly cited.

\begin{abstract}
Background: Studies of adult hippocampal neurogenesis (AHN) in laboratory rodents have raised hopes for therapeutic interventions in neurodegenerative diseases and mood disorders, as AHN can be modulated by physical exercise, stress and environmental changes in these animals. Since it is not known whether cell proliferation and neurogenesis in wild living mice can be experimentally changed, this study investigates the responsiveness of $\mathrm{AHN}$ to voluntary running and to environmental change in wild caught long-tailed wood mice (Apodemus sylvaticus).

Results: Statistical analyses show that running had no impact on cell proliferation $(p=0.44)$, neurogenesis $(p=0.94)$ or survival of newly born neurons $(p=0.58)$. Likewise, housing in the laboratory has no effect on AHN. In addition, interindividual differences in the level of neurogenesis are not related to interindividual differences of running wheel performance $\left(r_{s}=-0.09, p=0.79\right)$. There is a correlation between the number of proliferating cells and the number of cells of neuronal lineage $\left(r_{s}=0.63, p<0.00 I\right)$ and the number of pyknotic cells $\left(r_{s}=0.5, p=0.009\right)$, respectively.

Conclusion: Plasticity of adult neurogenesis is an established feature in strains of house mice and brown rats. Here, we demonstrate that voluntary running and environmental changes which are effective in house mice and brown rats cannot influence AHN in long-tailed wood mice. This indicates that in wild long-tailed wood mice different regulatory mechanisms act on cell proliferation and neurogenesis. If this difference reflects a species-specific adaptation or a broader adaptive strategy to a natural vs. domestic environment is unknown.
\end{abstract}

\section{Background}

In the dentate gyrus of the mammalian hippocampus progenitor cells continuously generate neurons throughout adulthood [1]. Adult hippocampal neurogenesis (AHN) occurs in various investigated mammals [2], including primates [3] and humans [4] but is low or missing in bats [5]. Among wild living mice and voles, levels of AHN can vary to a great extent, but it remains similar in taxonomic closely related species $[6,7]$. Two main findings have emerged from studies in laboratory mice and rats on the function of these new neurons and the regulation of AHN. First, the functional role of newly generated neurons has remained controversial. There have been reports that AHN correlates positively with hippocampus-dependent learning tasks, especially with spatial learning [8-11]. On the other hand, complete elimination of adult hippocampal neurogenesis has no or only minimal effects on a large number of behavioural measures in mice [12]. Second, 
adult neurogenesis in laboratory rodents varies extensively between species and strains $[13,14]$, and can be modulated by various internal and external factors. Triggers such as physical exercise, enriched environment $[15,16]$ and growth factors like BDNF or IGF-1 stimulate AHN [17]. Age, stress and impoverished environment in contrast have a negative regulatory effect on the production of new neurons [18-20].

Physical exercise is a strong stimulator of cell proliferation and neurogenesis. In laboratory rodents it enhances the amount of cell proliferation and neurogenesis up to three fold [21]. These rodent findings have attracted much interest, because triggering of AHN through physical exercise might improve cognitive abilities in disabled or healthy humans, possibly by inducing specific gene expression patterns $[22,23]$.

However, it remains an open question whether experimental data from rodents can be extrapolated to humans, or which species could serve as animal model -laboratory or wild rodents. It is also not known whether cell proliferation and neurogenesis in wild living mice can be experimentally modulated. Thus, this study investigates the responsiveness of AHN to voluntary running in the wild caught long-tailed wood mouse (Apodemus sylvaticus). Furthermore, we investigated whether individual differences in neurogenesis and level of voluntary exercise are related, and if environmental changes alter AHN.

The long tailed wood mouse is genetically one of the closest relative to Mus musculus [24]. Ecologically, it is also one of the best-studied wild mouse species. Wood mice are commonly distributed throughout Europe, parts of Asia and north-western Africa. They are characterized as agile animals with patrolling behaviour and good spatial memory having a territory size up to $25^{\prime} 000 \mathrm{~m}^{2}[25,26]$. In behavioural tests wood mice show moderately better learning abilities compared to bank voles [27].

In this study, proliferating cells were visualized with the endogenous marker Ki-67 [28-30], a chromosome-associated protein present during the active phase of the cell cycle $\left(G_{1}-M\right)$. Developing neurons were immunohistochemically detected with a marker against doublecortin (DCX). DCX is a microtubule-associated protein expressed in migrating cells and during the initial period of morphological maturation and functional integration of the developing neuron [31-33]. It has been shown that DCX is a reliable marker for neurogenesis since it monitors specifically progenitor cells of neuronal lineage and young neurons [34]. Pyknotic cells were visualized using a Giemsa stain.

We compared the relation of wheel running activity during 14 days and AHN in wild caught wood mice. In order to test for effects of captivity, AHN was assessed in animals immediately after capturing and compared to AHN in animals kept in home cages with and without running wheels.

\section{Results}

Exercise and cell proliferation, neurogenesis and apoptosis The three experimental groups, baseline, control and running group, (see Methods) were tested for differences in cell numbers. Statistic analysis of Ki67 positive cells (Fig. 1a) showed no difference in proliferation rates between the three experimental groups $(\mathrm{p}=0.443)$. Analysis of neurogenesis, using DCX as a marker for cells of neuronal lineage (Fig. 1b), also showed no group differences $(\mathrm{p}=$ 0.938 ). Likewise, comparison of the number of pyknotic cells (Fig. 1c) revealed no significant differences $(\mathrm{p}=$ 0.576). Data of cell counts are shown in Table 1, visualization of immunohistochemical stains are shown in Fig. 2 for Ki67 (Fig. 2a), DCX (Fig. 2b, d, e), and a Giemsastained pyknotic cell (Fig. 2c).

\section{Correlation of the numbers of proliferating cells, cells of neuronal lineage and pyknotic cells}

Analysis of the pooled data from all experimental groups showed a strong correlation between the number of proliferating cells and the number of cells of neuronal lineage $\left(r_{s}=0.63, p<0.001\right)$. Group-separated analysis revealed a correlation in both the running $\left(r_{s}=0.66, p=0.026\right)$ and the control group $\left(r_{s}=0.78, p=0.013\right)$. Correlation in the baseline group was marginally significant $\left(\mathrm{r}_{\mathrm{s}}=0.75, \mathrm{p}=\right.$ 0.052 ). Total numbers of pyknotic cells and proliferating cells were also correlated $\left(r_{s}=0.50, p=0.009\right)$, but there was no correlation between the number of DCX positiveand pyknotic cells $\left(r_{s}=0.18, p=0.387\right)$.

\section{Running and cell parameters}

There was no correlation between performance and the amount of Ki-67 positive cells $\left(r_{s}=0.29, p=0.39\right.$, Fig. 3a), cells of neuronal lineage $\left(r_{s}=-0.09, p=0.79\right.$, Fig. 3b) and pyknotic cells $\left(r_{s}=-0.38, p=0.28\right.$, Fig. $\left.3 c\right)$, respectively. Performing mice could be grouped in three activity classes. Five mice were allocated to the first category that did less than an average of 1000 revolutions per day. The second category comprised three animals that ran between 1000-3000 revolutions, whereas the third category included three animals that performed more than a daily amount of 10'000 revolutions on average. Daily running activity of each individual varied considerably. On average, the wild animals performed significantly less than $\mathrm{C} 57 \mathrm{BL} / 6$ laboratory mice, under identical experimental conditions, $(\mathrm{p}=0.047$; Klaus et al., in preparation).

No gender specific difference within experimental groups Within the limits of statistical power set by the low number of females in this study, no gender dependent dif- 

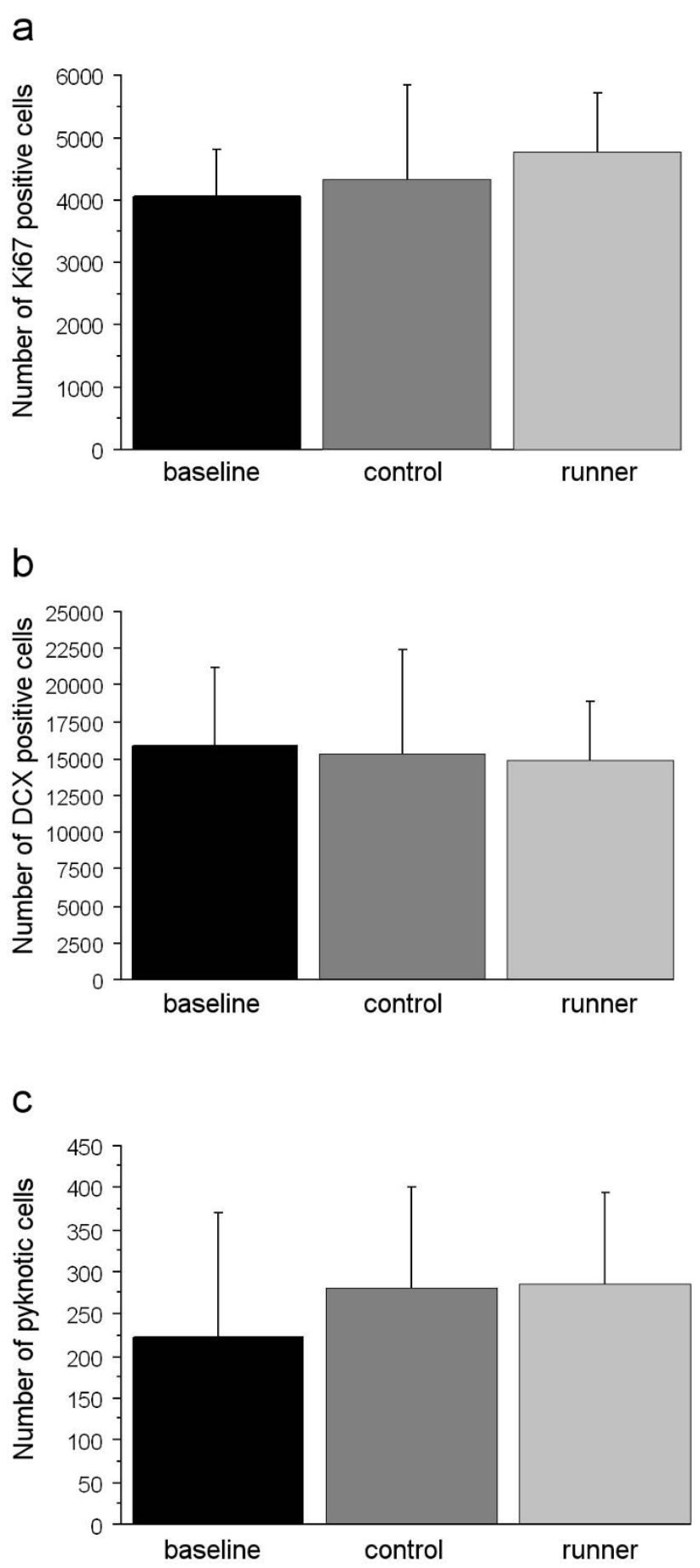

Figure I

Group comparison of cell numbers. Experimental groups (baseline = investigated directly after trapping; control = two weeks of laboratory housing; runner = two weeks of voluntary running) do not differ in their number of proliferating cells ( $\mathrm{a}, \mathrm{Ki} 67)$, young neurons (b, DCX) and pyknotic cells (c). Analysis was performed with general linear model. Bars represent SD. ference were found in any experimental group for any of the parameters investigated (data not shown).

\section{Discussion}

In this study we investigated for the first time whether wheel running has an impact on cell proliferation, neurogenesis and cell death in wild long-tailed wood mice, but found none.

\section{Voluntary running affects cell proliferation and} neurogenesis in laboratory rodents but not in wood mice Physical exercise leads to neuromorphological and neurobehavioural alterations in the brain of laboratory rodents. It increases cell proliferation and neurogenesis $[16,35]$, enhances dendritic spine density on granule cells $[36,37]$, stimulates neurotrophic factor activity [22,38] and correlates with improved cognitive functions in spatial $[35,39,40]$ and non-spatial memory tasks $[41,42]$. In rats, hippocampal BDNF is increased after two nights of free access to a running wheel [23] and a single week of exercise is sufficient to improve memory performance in the water maze task [43]. The effects of physical exercise on cell proliferation and neurogenesis, as well as neurobehavioral features, are age-independent [41,44-46].

Here, we demonstrate that in wild wood mice voluntary running has no impact on cell proliferation, neurogenesis and apoptosis in the hippocampus. Not only does physical exercise not influence cell proliferation and neurogenesis, but AHN seems also resistant to changes in the environment as indicated by the lack of differences between animals sacrificed immediately after trapping and those housed in the laboratory.

\section{Why is there no exercise effect in wood mice?}

Exercise-induced increase in neurogenesis and cell proliferation may be counterbalanced by stress, which has a suppressive effect on granule cell genesis [47]. However, as the extreme environmental change from natural living conditions to laboratory housing, be it with or without running wheel, did not cause changes in any AHN-related cellular processes, we expect that stress is not involved. In daily home cage observation we did not see any sign of stress or discomfort. No stereotypic behaviour could be detected [48]. In addition a previous study with wild wood mice showed that short-term captivity is not stressful enough to decrease adult neurogenesis [7].

In the natural habitat of wild wood mice daily running belongs to their behavioural pattern [25]. If running stimulates cell proliferation and neurogenesis similarly in wild mice as it does in laboratory rodents it might be argued that proliferation and neurogenesis in the natural habitat proceed at a level that, under laboratory conditions, is just 

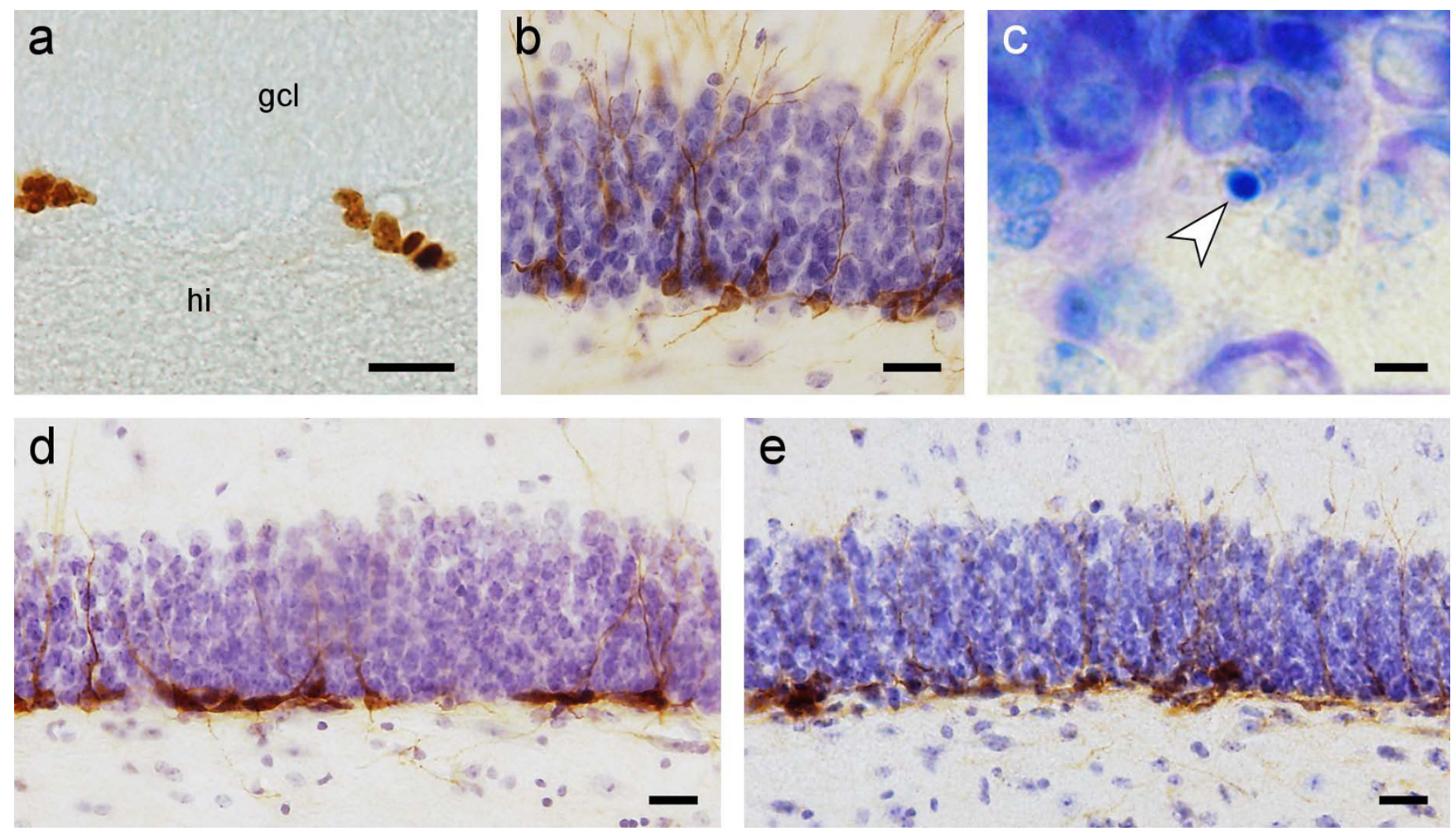

\section{Figure 2}

Immunohistochemistry staining. a: Ki67 staining of the septal part of the dentate gyrus subgranular zone. Two clusters of proliferating cells, indicated in brown, are located in the subgranular zone (gcl: granule cell layer; hi: hilus). Scale bar $=20 \mu \mathrm{m}$. b: DCX positive cells (brown) in the septal part of the dentate gyrus subgranular zone. The DCX immunostaining is counterstained with haematoxylin. Young neurons extend long dendrites into the granular and molecular cell layer. Scale bar $=20 \mu \mathrm{m}$ c: Condensed chromatin of a pyknotic cell in the subgranular zone is visualized with Giemsa staining in plastic embedded tissue. Arrow indicates a pyknotic cell. Scale bar $=5 \mu \mathrm{m}$ d: Qualitative comparison of the amount of young neurons (stained in brown) in the subgranular zone of a baseline wood mouse (d) and a running wood mouse (e). No difference in the number of DCX positive cells can be seen. Scale bar $=20 \mu \mathrm{m}$.

being maintained by access to a running wheel. Therefore, a ceiling effect of AHN, reached through natural activity, might be the reason why running under laboratory conditions does not result in a further enhancement, as the production of new neurons would be already at the maximum. However, individual performance of wood mice varied considerably without effecting AHN. Some mice ran on a low level of about 100-3000 revolutions while other animals performed on higher levels of 16 '000-40'000 revolutions on average. In laboratory mice, three hours of performance ( 3500 mean daily wheel revolutions) is enough to significantly increase cell proliferation, cell survival and total number of new neurons [44]. Restricting the analysis to wild mice which ran

Table I: Estimates of proliferating cells, young neurons and pyknotic cells in the dentate gyrus

\begin{tabular}{lrrrrrrr}
\hline & baseline & control & running & CE & Sampling sites* & Sections analyzed* & Cells counted* \\
\hline Ki67 & $4^{\prime} 047$ & $4^{\prime} 315$ & $4^{\prime} 744$ & 0.049 & & $14(12-15)$ & $695(356-1001)$ \\
SD & 772 & $I^{\prime} 525$ & 977 & & & \\
DCX & $1^{\prime} 840$ & $1^{\prime} 204$ & $15^{\prime} 871$ & 0.09 & $339(273-486)$ & $14(10-16)$ & $157(64-319)$ \\
SD & $5^{\prime} 426$ & $7^{\prime} 238$ & $4^{\prime} 019$ & & & $27(21-30)$ \\
pyknotic & 223 & 279 & 283 & 0.09 & & $48(17-78)$ \\
SD & 148 & 122 & 110 & & & \\
\hline
\end{tabular}

Average numbers of young neurons, visualized immunohistochemically through Doublecortin (DCX), are obtained from stereological estimates using the optical fractionator method. Proliferating cells (Ki67 positive cells) and pyknotic cells are counted manually and multiplied by the section fraction to estimate total cell numbers. All parameters were analyzed in every sixth section. SD stands for standard deviation and CE is coefficient of error. *Values are means with ranges in parentheses. 


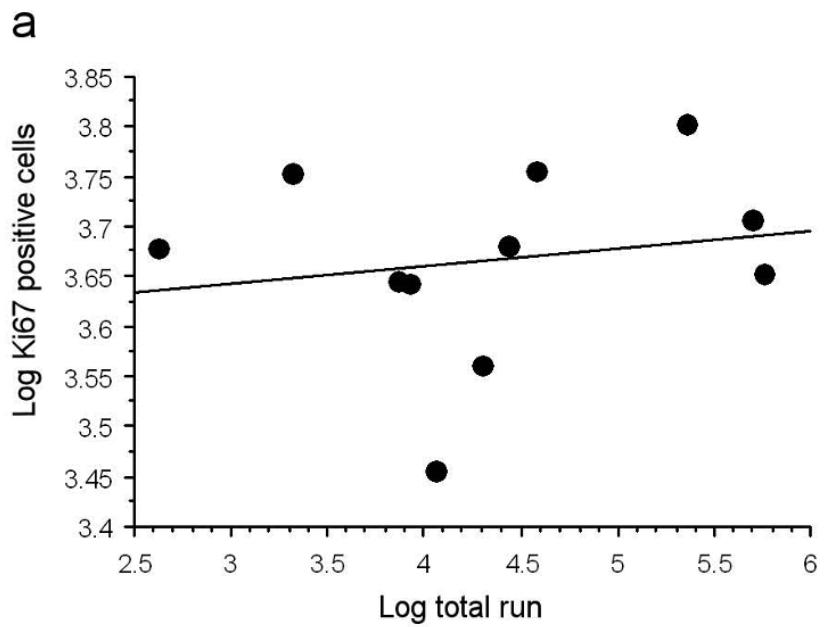

b

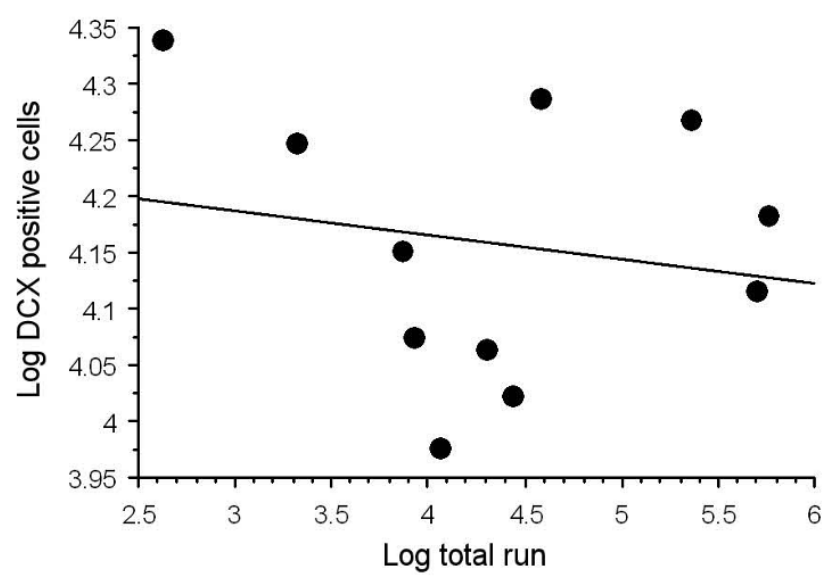

C

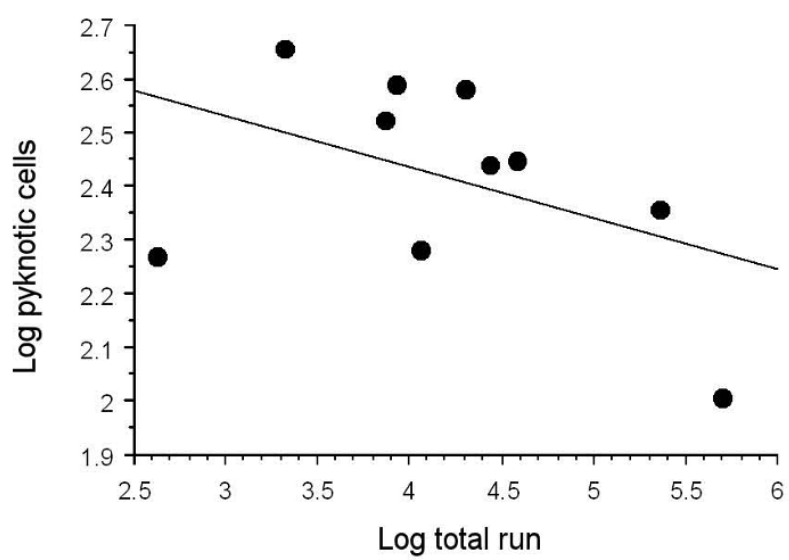

Figure 3

Performance and cell parameters. There is no correlation between performance (log total run) over the two weeks and the amount of proliferating cells ( $\mathrm{a}, \mathrm{Ki} 67$ positive cells), young neurons (b, DCX positive cells) and pyknotic cells (c). Data are represented in logarithmic numbers. between 3500 and 63'000 revolutions per active phase, no exercise related alteration was found in these animals when compared to non runners or mice of the baseline group. Even if low performance might be enough to maintain a natural high level of AHN in wild mice, we would expect a decrease of AHN in animals kept without access to a running wheel, which is not the case. The low rho values of all correlations also stress the independence of cell proliferation, neurogenesis or cell death from physical activity.

Natural living conditions may regulate AHN over a time span that outlast the experimental period of two weeks. A long-term regulation that maintains a constant pool of functionally distinct young neurons may be an adaptive strategy in the face of constantly changing natural living conditions. To our knowledge there is no data on the duration of a running-induced effect on adult neurogenesis in house mice and brown rats once the exercise has ceased. In this context it is remarkable that laboratory housing of wild wood mice does not lead to alterations in AHN despite the environmental change from nature to laboratory cage, which one could consider as a severe loss of environmental stimuli.

\section{AHN stimulation by running - a species-specific effect or a trait of domestication?}

In laboratory mice regulatory mechanisms of proliferation and neurogenesis are related to the genetic background $[13,14]$, which in turn is the result of unintentional selective breeding that can have profound consequences on physiology, morphology and behaviour. It is unknown if the adaptive response of AHN to stimulating factors is a naturally occurring feature which laboratory animals have inherited from their ancestors. At least, the finding that running and environmental changes affect AHN in laboratory rodents but not in wild wood mice indicates that different regulatory mechanisms are operative in these species. Another possible source for regulation differences between wild and laboratory rodents is domestication. Domestication is accompanied by an irreversible reduction of $10.2 \%$ of hippocampus volume in rats [49] and changes in behaviour including a reduced sensitivity to predators in rodents, suggesting diminished anxiety and fear responses [50]. In a long-term study of selective breeding exclusively for tameness in silver foxes, Trut (1999) has shown that in the course of domestication the timing of the postnatal development of neurochemical and neurohormonal mechanisms changes [51]- alterations that have the potential to affect the development of the hippocampus as one of the brain structures that differentiate late in ontogenesis. 


\section{Conclusion}

Although this study is limited by the fact that we only investigated one species, it emphasizes the importance to examine AHN in a broader, evolutionary context [52]. Attempts to translate data from rodents to man in the field of adult neurogenesis should be based on a large variety of possible regulatory mechanisms. Studies in humans are limited for obvious reasons, and it is not clear if humans should be characterized as domesticated or wild, or if this characterization is required at all. Studying factors regulating AHN in different rodent species is a necessary step in charting white spots on the map of regulatory pathways of AHN. The finding that neither running nor environment influence adult hippocampal neurogenesis in wild longtailed wood mice (one of the closest relatives of house mice) indicates that different regulatory mechanisms are operative in this species compared to laboratory mice and rats. Whether these findings reflect domestication effects, specific genetic background or species-specific environmental adaptation of the animals is yet unknown. More studies on various wild mouse species are required to verify differences in regulatory mechanisms of AHN between wild and laboratory mice, hopefully elucidating the source of these differences. The widespread use of laboratory rodents in translational research on AHN makes it important to address these questions.

\section{Methods \\ Animal}

27 wood mice (Apodemus sylvaticus), 21 males and six females, were trapped in live-traps in the park around the University of Zürich in spring. Traps were controlled every 2 hours and mice either immediately perfused (baseline group, total 7 ( $5 \mathrm{~m} / 2 \mathrm{f})$ ) or singly housed for 14 days in cages containing either a running wheel (running group, total $11(9 \mathrm{~m} / 2 \mathrm{f})$ ) or no environmental enrichment (control group, total $9(7 \mathrm{~m} / 2 \mathrm{f}))$. Mice had free access to running wheels $(\varnothing 14 \mathrm{~cm})$. All cages were provided with bedding material, fresh hay, water and standard laboratory mouse food pellets supplemented with fruits and seeds. Mice were exposed to a 12 hours light-dark phase. Wild animals were classified as juvenile, adult or old based on tooth wear, sexual maturity, marks of previous pregnancies and body weight in correlation to season as done and described before [6]. All experiments were approved by the veterinary office of the Kanton of Zürich.

\section{Histology}

Mice of the running and control groups were sacrificed immediately after the active phase. They were anaesthetized with Pentobarbital (50 mg/kg body weight) and perfused transcardially with cold phosphate-buffered saline (PBS) followed by $0.6 \%$ sodium sulphide solution in PBS and cold $4 \%$ paraformaldehyde with $15 \%$ saturated picric acid in PBS. Brains were removed, hemispheres separated and postfixed over night. After postfixation, right hemispheres were transferred into 30\% sucrose in PBS and frozen after saturation. For immunohistochemistry $40 \mu \mathrm{m}$ sagittal sections were cut and stored at $-20^{\circ} \mathrm{C}$ in a cryoprotective solution until further processing. For Giemsa staining left hemispheres were dehydrated for a total of $9 \mathrm{~h}$ in alcohol $(4 \times 70 \%, 4 \times 96 \%, 2 \times 99 \%)$, incubated for ten days in infiltration solution and embedded in glycomethacrylate (Technovit 7100, Heraeus Kulzer GmbH, Wehrheim, Germany).

\section{Ki67 and DCX staining}

For Ki67 immunohistochemistry, free floating sections were incubated for epitope retrieval in citrate buffer, $\mathrm{pH}$ 6.0, at $90^{\circ} \mathrm{C}$ for $40 \mathrm{~min}$, followed by incubation in endogenous peroxidase blocking reagent, $0.6 \% \mathrm{H}_{2} \mathrm{O}_{2}$ in TBS-Triton $(0.05 \%$ Triton X-100 in TBS, pH 7.4) for 30 min at room temperature (RT). For DCX immunohistochemistry, free floating sections were microwaved at $600 \mathrm{~W}$ in citrate buffer, $\mathrm{pH}$ 6.0, for $1.5 \mathrm{~min}$ for epitope retrieval, followed by incubation in endogenous peroxidase blocking reagent (see above). Thereafter sections were preincubated in 2\% Serum (for Ki67: NGS; for DCX: NRS) + 0.1\% $\mathrm{BSA}+0.25 \%$ Triton in TBS, for $60 \mathrm{~min}$ at RT. Afterwards, sections were incubated with primary antibody Ki67 (polyclonal rabbit NCL-Ki67p, Novocastra, 1:5000 in preincubation solution) and DCX (polyclonal goat IgG, Santa Cruz Biotechnology, 1:1000 in preincubation solution) overnight at $4{ }^{\circ} \mathrm{C}$. Incubation with secondary antibodies (for Ki67: biotinylated goat anti-rabbit IgG 1:1000 + $2 \% \mathrm{NGS}+0.1 \% \mathrm{BSA}$ in TBS; For DCX: rabbit anti-goat IgG, Vectastain Elite ABS Kit, 1:1000 + 2\%NRS + 0.1\%BSA in TBS) was performed for two hours followed by incubation with streptavidin-biotin complex (Vectastain Elite ABC kit) and stained with $\mathrm{DAB}$ as chromogen. Until incubation with the primary antibody all rinses in between incubations were made with TBS-Triton, afterwards with TBS alone.

\section{Giemsa staining}

Glycomethacrylate-embedded left hemispheres were cut horizontally at $20 \mu \mathrm{m}$ with a metal knife on a Leitz Rotary microtome. Every sixth section was stained according to the protocol of Iniguez [53]. Incubation in Giemsa staining solution (Giemsa stock solution 1.09204.0500, Merck, Darmstadt, Germany) diluted 1: 10 in buffer (67 mmol KH2PO4) at RT for 40 min., rinsed in $1 \%$ acetic acid for $10 \mathrm{sec}$. and differentiated in $3 \times 99 \%$ alcohol, cleared in Xylol and mounted with Eukitt.

\section{Measurements \\ Run distance}

A controller system (AMS Software and Electronic GmbH, Flensburg Germany) registered the animal's running activity in one hour bins. 


\section{Total DCX positive cell number}

The number of DCX positive cells was estimated in every sixth section using the optical fractionator [54] with StereoInvestigator software (MicroBrightField Inc. Williston, USA). This stereological method provides unbiased estimates of neuron number. Assumptions about neuron size and shape are not necessary and estimates are unaffected by tissue shrinkage. The microscope used was a Zeiss Axioplan with a $100 \times$ oil-immersion lens. Cells were counted in a frame of $30-30 \mu \mathrm{m}$ with a x, y-step size of $120 \mu \mathrm{m}$. Total DCX-positive cell number $(\mathrm{N})$ is calculated using the formula $\mathrm{N}=\sum \mathrm{Q}^{-} \times(\mathrm{t} / \mathrm{h}) \times(1 / \mathrm{asf}) \times 1 / \mathrm{ssf}$, where $\mathrm{Q}^{-}=$ total number of cells counted, $\mathrm{t}=$ section thickness, $\mathrm{h}=$ height of optical disector, asf $=$ area of sampling fraction $=$ $\mathrm{a}$ (frame)/a(x,y step) and ssf = section sampling fraction.

\section{Total Ki67 positive cell number}

Proliferating cells were counted exhaustingly in every sixth section on an Olympus light microscope using a $63 \times$ oil-immersion lens and multiplied by the section sampling fraction to obtain estimated total cell number. Cells in the top focal plane of the section were not counted. All Ki67 positive cells in the subgranular layer (SGL) and in the granule cell layer (GCL) (reaching 1/3 into cell layer; towards molecular layer) of the right hemisphere were counted.

\section{Total pyknotic cell number}

Estimates of total apoptotic cells were made as described for Ki67, using a Zeiss Axioplan microscope with a $40 \times$ oil-immersion lens. Pyknotic cells were easily identified by their strongly stained nuclei whose chromatin condensed into peripherally ( $\mathrm{C}$ or doughnut shape), solid or multiple cell bodies [7]. Pyknotic cells were counted manually in the same zone as proliferating cells. Again, cells in the top focal plane of the section were not considered.

\section{Statistics}

Only adult animals are included in statistical calculations. Group comparisons of total number of proliferating cells, new born neurons and pyknotic cells were performed with general linear model (GLM). Statistical significance level was determined at 5\%. Correlation analyses were performed with paired two-group Spearman rank correlation. Statistical analyses were performed with SPSS software (version 17).

The brightness and contrast of microphotographs were adjusted to resemble the appearance of the sections under the microscope. No local changes were made to the images.

\section{Authors' contributions}

TH and FK participated in the design of the study, trapped and perfused the mice, carried out the experiment, cut the brains and processed sections for immunohistochemistry. Furthermore, they performed statistical analysis, interpreted data and drafted manuscript. HPL provided the funding and participated in writing the manuscript. IA conceived of the study, helped designing it and participated in writing the manuscript. All authors read and approved the final manuscript.

\section{Acknowledgements}

We are grateful to L. Slomianka for support in stereological concerns and critical reading of the manuscript. We thank $G$. Anzenberger and H. Kunz for the permission to trap wild wood mice in the University primate station, and nursery respectively. We also thank $L$. Sarasz for constructing running wheel cages. This work was supported by the NCCR 'Neural Plasticity and Repair' and Swiss National Science Foundation.

\section{References}

I. Gage FH: Mammalian neural stem cells. Science 2000, 287(5457): | 1433-I438.

2. Taupin $\mathrm{P}, \mathrm{Gage} \mathrm{FH}$ : Adult neurogenesis and neural stem cells of the central nervous system in mammals. J Neurosci Res 2002, 69(6):745-749.

3. Kornack DR, Rakic P: Continuation of neurogenesis in the hippocampus of the adult macaque monkey. Proc Natl Acad Sci USA 1999, 96( (10):5768-5773.

4. Eriksson PS, Perfilieva E, Bjork-Eriksson T, Alborn AM, Nordborg C, Peterson DA, Gage FH: Neurogenesis in the adult human hippocampus. Nat Med I998, 4(II):1313-1317.

5. Amrein I, Dechmann DK, Winter Y, Lipp HP: Absent or low rate of adult neurogenesis in the hippocampus of bats (Chiroptera). PLOS ONE 2007, 2(5):e455.

6. Amrein I, Slomianka L, Poletaeva II, Bologova NV, Lipp HP: Marked species and age-dependent differences in cell proliferation and neurogenesis in the hippocampus of wild-living rodents. Hippocampus 2004, I4(8): 1000-1010.

7. Amrein I, Slomianka L, Lipp HP: Granule cell number, cell death and cell proliferation in the dentate gyrus of wild-living rodents. Eur J Neurosci 2004, 20( I 2):3342-3350.

8. Drapeau E, Mayo W, Aurousseau C, Le Moal M, Piazza PV, Abrous $\mathrm{DN}$ : Spatial memory performances of aged rats in the water maze predict levels of hippocampal neurogenesis. Proc Natl Acad Sci USA 2003, 100(24): $14385-14390$.

9. Dupret D, Fabre A, Dobrossy MD, Panatier A, Rodriguez JJ, Lamarque S, Lemaire V, Oliet SH, Piazza PV, Abrous DN: Spatial learning depends on both the addition and removal of new hippocampal neurons. PLoS Biol 2007, 5(8):e2I4.

10. Madsen TM, Kristjansen PE, Bolwig TG, Wortwein G: Arrested neuronal proliferation and impaired hippocampal function following fractionated brain irradiation in the adult rat. Neuroscience 2003, I I 9(3):635-642.

II. Shors TJ, Miesegaes G, Beylin A, Zhao M, Rydel T, Gould E: Neurogenesis in the adult is involved in the formation of trace memories. Nature 200I, 4 10(6826):372-376.

12. Meshi D, Drew MR, Saxe M, Ansorge MS, David D, Santarelli L, Malapani $C$, Moore $\mathrm{H}$, Hen R: Hippocampal neurogenesis is not required for behavioral effects of environmental enrichment. Nat Neurosci 2006, 9(6):729-73I.

13. Kempermann G, Kuhn HG, Gage FH: Genetic influence on neurogenesis in the dentate gyrus of adult mice. Proc Natl Acad Sci USA 1997, 94(19): 10409-10414.

14. Kempermann G, Gage FH: Genetic influence on phenotypic differentiation in adult hippocampal neurogenesis. Brain Res Dev Brain Res 2002, I34(I-2): I-I2.

15. Kempermann G, Kuhn HG, Gage FH: More hippocampal neurons in adult mice living in an enriched environment. Nature 1997, 386(6624):493-495.

16. van Praag H, Kempermann G, Gage FH: Running increases cell proliferation and neurogenesis in the adult mouse dentate gyrus. Nat Neurosci 1999, 2(3):266-270. 
17. Cotman CW, Berchtold NC, Christie LA: Exercise builds brain health: key roles of growth factor cascades and inflammation. Trends Neurosci 2007, 30(9):464-472.

18. Kuhn HG, Dickinson-Anson H, Gage FH: Neurogenesis in the dentate gyrus of the adult rat: age-related decrease of neuronal progenitor proliferation. I Neurosci 1996, I 6(6):2027-2033.

19. McEwen BS: Stress and hippocampal plasticity. Annu Rev Neurosci 1999, 22:105-122.

20. Pietropaolo S, Sun Y, Li R, Brana C, Feldon J, Yee BK: The impact of voluntary exercise on mental health in rodents: a neuroplasticity perspective. Behav Brain Res 2008, I 92(I):42-60.

21. Olson AK, Eadie BD, Ernst C, Christie BR: Environmental enrichment and voluntary exercise massively increase neurogenesis in the adult hippocampus via dissociable pathways. Hippocampus 2006, I6(3):250-260.

22. Tong L, Shen H, Perreau VM, Balazs R, Cotman CW: Effects of exercise on gene-expression profile in the rat hippocampus. Neurobiol Dis 2001, 8(6): I046-1056.

23. Molteni R, Ying Z, Gomez-Pinilla F: Differential effects of acute and chronic exercise on plasticity-related genes in the rat hippocampus revealed by microarray. Eur J Neurosci 2002 , I 6(6): II07-III6.

24. Michaux JR, Chevret P, Filippucci MG, Macholan M: Phylogeny of the genus Apodemus with a special emphasis on the subgenus Sylvaemus using the nuclear IRBP gene and two mitochondrial markers: cytochrome b and I2S rRNA. Mol Phylogenet Evol 2002, 23(2): I23-I36.

25. Niethammer J, Krapp F: Apodemus sylvaticus. In Handbuch der Säugetiere Europas Volume I. Edited by: Niethammer J, Krapp F. Wiesbaden: Akademische Verlagsgesellschaft; 1982:337-358.

26. Stopka P, Macdonald DW: Way-marking behaviour: an aid to spatial navigation in the wood mouse (Apodemus sylvaticus). BMC Ecol 2003, 3:3.

27. Galsworthy MJ, Amrein I, Kuptsov PA, Poletaeva II, Zinn P, Rau A, Vyssotski A, Lipp HP: A comparison of wild-caught wood mice and bank voles in the Intellicage: assessing exploration, daily activity patterns and place learning paradigms. Behav Brain Res 2005, I 57(2):21|-217.

28. Starborg M, Gell K, Brundell E, Hoog C: The murine Ki-67 cell proliferation antigen accumulates in the nucleolar and heterochromatic regions of interphase cells and at the periphery of the mitotic chromosomes in a process essential for cell cycle progression. J Cell Sci I996, I09(Pt I): |43-I53.

29. Scholzen T, Gerdes J: The Ki-67 protein: from the known and the unknown. J Cell Physiol 2000, I 82(3):3 I I-322.

30. Kee N, Sivalingam S, Boonstra R, Wojtowicz JM: The utility of Ki67 and $B r d U$ as proliferative markers of adult neurogenesis. J Neurosci Methods 2002, I I 5(I):97-I05.

31. Koizumi H, Higginbotham H, Poon T, Tanaka T, Brinkman BC, Gleeson JG: Doublecortin maintains bipolar shape and nuclear translocation during migration in the adult forebrain. Nat Neurosci 2006, 9(6):779-786.

32. Francis F, Koulakoff A, Boucher D, Chafey P, Schaar B, Vinet MC, Friocourt G, McDonnell N, Reiner O, Kahn A, McConnell SK, BerwaldNetter Y, Denoulet P, Chelly J: Doublecortin is a developmentally regulated, microtubule-associated protein expressed in migrating and differentiating neurons. Neuron 1999 23(2):247-256.

33. Feng $Y$, Walsh CA: Protein-protein interactions, cytoskeletal regulation and neuronal migration. Nat Rev Neurosci 200I, 2(6):408-416.

34. Rao MS, Shetty AK: Efficacy of doublecortin as a marker to analyse the absolute number and dendritic growth of newly generated neurons in the adult dentate gyrus. Eur J Neurosci 2004 I 9(2):234-246.

35. van Praag $H$, Christie BR, Sejnowski TJ, Gage FH: Running enhances neurogenesis, learning, and long-term potentiation in mice. Proc Natl Acad Sci USA 1999, 96(23): | 3427-| 343 |.

36. Redila VA, Christie BR: Exercise-induced changes in dendritic structure and complexity in the adult hippocampal dentate gyrus. Neuroscience 2006, I37(4): I299-I307.

37. Zhao C, Teng EM, Summers RG Jr, Ming GL, Gage FH: Distinct morphological stages of dentate granule neuron maturation in the adult mouse hippocampus. I Neurosci 2006, 26(I):3-II.
38. Neeper SA, Gomez-Pinilla F, Choi J, Cotman CW: Physical activity increases $m R N A$ for brain-derived neurotrophic factor and nerve growth factor in rat brain. Brain Res 1996, 726(I2):49-56.

39. Vaynman S, Ying Z, Gomez-Pinilla F: Hippocampal BDNF mediates the efficacy of exercise on synaptic plasticity and cognition. Eur J Neurosci 2004, 20( I 0):2580-2590.

40. Adlard PA, Perreau VM, Engesser-Cesar C, Cotman CW: The timecourse of induction of brain-derived neurotrophic factor mRNA and protein in the rat hippocampus following voluntary exercise. Neurosci Lett 2004, 363(I):43-48.

4I. Samorajski T, Delaney C, Durham L, Ordy JM, Johnson JA, Dunlap WP: Effect of exercise on longevity, body weight, locomotor performance, and passive-avoidance memory of C57BL/6] mice. Neurobiol Aging 1985, 6(I): 17-24.

42. Eisenstein SA, Holmes PV: Chronic and voluntary exercise enhances learning of conditioned place preference to morphine in rats. Pharmacol Biochem Behav 2007, 86(4):607-615.

43. Vaynman S, Ying Z, Gomez-Pinilla F: The select action of hippocampal calcium calmodulin protein kinase II in mediating exercise-enhanced cognitive function. Neuroscience 2007, | 44(3):825-833.

44. Holmes MM, Galea LA, Mistlberger RE, Kempermann G: Adult hippocampal neurogenesis and voluntary running activity: circadian and dose-dependent effects. I Neurosci Res 2004, 76(2):216-222.

45. Vasuta C, Caunt C, James R, Samadi S, Schibuk E, Kannangara T, Titterness AK, Christie BR: Effects of exercise on NMDA receptor subunit contributions to bidirectional synaptic plasticity in the mouse dentate gyrus. Hippocampus 2007, I 7( I 2): | 20 I- I 208.

46. Kempermann G, Kuhn HG, Gage FH: Experience-induced neurogenesis in the senescent dentate gyrus. J Neurosci 1998 , I 8(9):3206-32 I2

47. Gould E, Tanapat P: Stress and hippocampal neurogenesis. Biol Psychiatry 1999, 46( I I): | 472-I479.

48. Cabib S, Puglisi-Allegra S, Oliverio A: Chronic stress enhances apomorphine-induced stereotyped behavior in mice: involvement of endogenous opioids. Brain Res 1984, 298(I): $138-140$.

49. Kruska D: Vergleichend-quantitative Untersuchungen an den Gehirnen von Wander- und Laborratten II. Volumenvergleich allokortikaler Hirnzentren. J Hirnforsch 1975, I 6:485-496

50. Wolff J: Laboratory Studies with Rodents: Facts or Artifacts? BioScience 2003, 53(4):42I-427.

51. Trut L: Early Canid Domestication: The Farm-Fox Experiment. American Scientist 1999, 87:160-169.

52. Amrein I, Lipp HP: Adult hippocampal neurogenesis of mammals: evolution and life history. Biol Lett 2009, 5: |4|-|44.

53. Iniguez C, Gayoso MJ, Carreres J: A versatile and simple method for staining nervous tissue using Giemsa dye. I Neurosci Methods 1985, I3(I):77-86

54. West MJ, Slomianka L, Gundersen HJ: Unbiased stereological estimation of the total number of neurons in thesubdivisions of the rat hippocampus using the optical fractionator. Anat $\operatorname{Rec} 1991,23$ I(4):482-497.

Publish with Bio Med Central and every scientist can read your work free of charge

"BioMed Central will be the most significant development for disseminating the results of biomedical research in our lifetime. "

Sir Paul Nurse, Cancer Research UK

Your research papers will be:

- available free of charge to the entire biomedical community

- peer reviewed and published immediately upon acceptance

- cited in PubMed and archived on PubMed Central

- yours - you keep the copyright 